\title{
Small, quick grants proposed as lifeline
}

\section{Washington}

US SCIENTISTS, believing that there is no time to waste, last week urged their government to fund hundreds of small collaborations with their Russian counterparts with part of $\$ 400$ million set aside for the destruction of nuclear weapons in the former Soviet Union. Under the plan, conceived during a two-day workshop held earlier this month at the National Academy of Sciences (NAS), those scientists who already hold federal research grants would identify partners in the former Soviet Union and provide them with money for vitally needed materials and equipment, visits to the United States, and collaborative research.

"If we wait too long, they'll be dead", says one participant, F. Albert Cotton, a professor of chemistry at Texas A\&M University. "I'd hope that we could do something by May or June, certainly no later than six months from now."

The proposal would keep active in the former Soviet Union those civilian scientists whose ability to carry out research has been severely curtailed by the political and economic chaos in the various republics. The goal is both to keep Russian scientists productive and to strengthen US science by tapping into a rich new source of available talent. The programme would draw as much as $\$ 10$ million from a fund created last fall by the US Congress to help the former Soviet Union to dismantle its nuclear arsenal and to employ those who built those weapons. The Bush Administration has already pledged to spend $\$ 25$ million from that fund on an international science centre (see Nature 355, 756; 1992).

The latest proposal is contained in a report issued last week by a group of 120 scientists and science administrators from government, business and the academic community who met on 2-3 March under the auspices of the NAS. The 23-page report, sent to D. Allan Bromley, the presi-

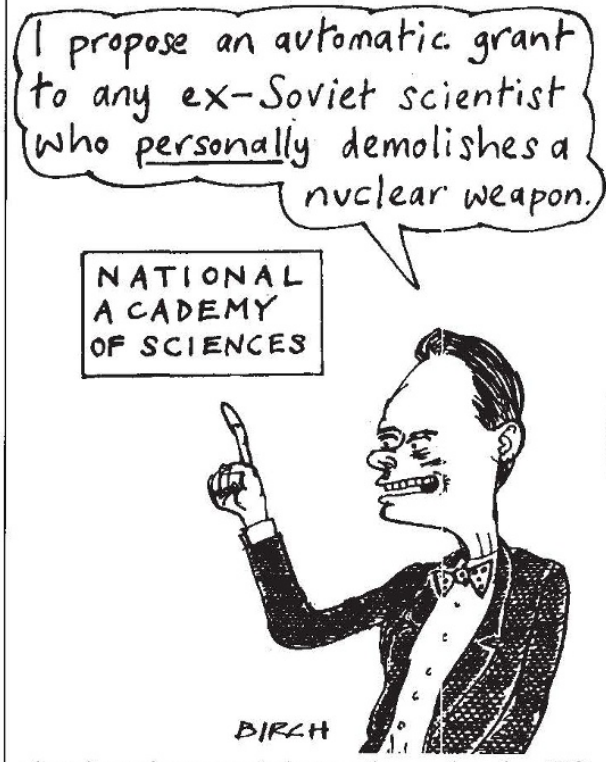

dent's science adviser, also asks the US government to spend $\$ 5-10$ million on large-scale bilateral research projects and $\$ 25$ million to foster technology with commercial potential, as well as helping to create a fund of $\$ 50-\$ 100$ million to preserve the most important research labora- tories in the former Soviet Union. It also urges the administration to adopt a proposal by US Representative George Brown (Democrat, California) for a binational foundation, endowed with $\$ 200$ million from public and private sources, to support joint research projects.

Bromley invited the academy to tackle the scientific crisis in the former Soviet Union after Boris Yeltsin, president of the Russian Republic, asked President George Bush for technological assistance during a meeting between the two leaders in late January. Bromley and Frank Press, president of the NAS, discussed the report during a hearing earlier this week before the Foreign Relations Committee of the US Senate.

There was no consensus at the academy meeting on how quickly such collaborations should be set up, nor on the best way to arrange them. Several participants favoured the approach used by a programme already under way at the US National Institutes of Health (see story below), which follows normal NIH procedures but allows for a slightly abridged proposal and a somewhat more rapid review. Other scientists preferred a radically shortened procedure that relies on the judgement of the grant holder, requires no more than a one-page description of the collaborator and the collaboration, and takes only a few weeks. The latter is what David Pines, a physicist at the University of Illinois and a participant at the workshop, suggested in a letter sent in December to Bromley and Walter Massey, direc-

\section{"Our motivation is to do good science"}

Seven US scientists received grants this month from the US National Institutes of Health (NIH) to work with their colleagues in the former Soviet Union. But NIH officials believe strongly that not even a scientific crisis is reason enough to abandon their system of picking the most worthy proposals.

While many of their colleagues are urging the US government to act quickly (see main story), these scientists say that the old ways are also the best. Paul Neiman, who heads the basic science division at the Fred Hutchinson Cancer Center in Seattle, Washington, has just added Victor Lobanekov and two associates at the All Union Cancer Research Center in Moscow to Neiman's existing NIH grant to study oncogenes in chickens. Neiman, who met Lobanekov in 1989 , says that he would not collaborate with a colleague whom he did not already know well, and does not mind waiting four to six months to learn whether his research passes muster with NIH.

"It's great that we could help out Victor," Neiman says about his three-year, $\$ 60,000$ grant from NIH's Fogarty International Center. "But our motivation is to do good science, not to provide humanitarian aid."

Douglas Berg of Washington University in St Louis, Missouri, who will be working on the metabolic regulation of bacteria with Alexander Mironov and the eight members of his laboratory at the Institute of Genetics and the Selection of
Industrial Microorganisms in Moscow, agrees that haste might make waste. "Experiments have to be planned", he says, "and I think what we'll be doing is better because of the review."

Last year, the Fogarty Center began a programme for existing NIH grantholders who wanted to collaborate with colleagues in Latin America and the formerly communist countries of Eastern Europe. Last fall, the programme added countries from the former Soviet Union itself, and on 6 March it announced 12 such awards.

Those awards were part of a pool of 55 requests received last fall- a success rate that barely exceeds 20 per cent. The fairly detailed proposals were processed in the same way as any NIH grant application - a thorough review by a panel of their peers, and a second review by an advisory body to the center. Last month the center began to process a second round of 80 applications, including 26 that involve scientists from the new republics. Officials expect that a similar percentage will be successful after a final review is completed in May.

Philip Schambra, director of the Fogarty Center, says that he will resist any pressure either to speed up the process or to conduct a less thorough review. "We don't want to be open to criticism that we threw money away", says an assistant, Gray Handley. "You need more than one page to conduct a proper review, and to be able to justify your decision." J.D.M. 


\section{Science cements Chinese ties}

tor of the National Science Foundation (NSF).

"There are literally hundreds of people out there who, with a modest add-on to their existing NSF grant, could adopt research groups in the former Soviet Union", Pines says. "The money could be used to fly them here, bring them up to date, and arrange a mutually beneficial collaboration on a significant problem once they return to Russia. The point is to get a great number of people over here, as quickly as possible.'

As with all recommendations that ask for more, the chief question is how to pay for it. Using money from the special fund set up last fall is attractive for two reasons: it protects the budgets of domestic research agencies, and it relies on money already appropriated.

But at a time when millions of US workers are unemployed and the federal deficit is approaching $\$ 400,000$ million, the notion of foreign aid is not a popular one. Recognizing that fact, those who attended the workshop hasten to explain that such a programme would benefit the United States as much as it helps the former Soviet Union.

"In order to have a free market in the former Soviet Union, which we want to foster, you need a strong science and technology base", explains Glenn Schweitzer, an expert on Central and Eastern Europe at the academy. "We also want to keep weapons scientists in place, working on civilian projects, instead of letting them go off and work for somebody that could threaten us. In addition, if we don't do it, the Japan and the Europeans will." Jeffrey Mervis

\section{Jerusalem}

ISRAEL has taken advantage of the high standing of its scientists in China to bring about full diplomatic relations between the two countries.

THE opening of a fụlly staffed embassy in Beijing in January ends a 40 -year diplomatic silence between the two countries. Although in the mid-1980s China began to accept tourists visiting on group visas, scientists were the only Israelis permitted to enter the country on individual visas. Despite the official cold shoulder shown to most of their countrymen, these scientists were greeted warmly by their Chinese colleagues.

Reuven Merhav, an Israeli diplomat who had worked in Hong Kong, decided to put that affection to the test shortly after being appointed director-general of the Israeli Foreign Ministry in November 1988. He asked Joshua Jortner, president of the Israel Academy of Sciences, and its director, MeirZadok, if the academy would like to establish an Israeli scientific centre in China. The academy officials quickly agreed, and in May 1989 they dispatched a three-person team to Beijing to sound out leading members of the Chinese scientific community.

The trip was a success. "They thought we were a scientific superpower," Zadok says with a laugh. In fact, Zeev Tadmor, a chemist who is now head of the Technion in Haifa, discovered that an undergraduate textbook he wrote with C.G. Gogos, Principles of Polymer Processing, had

\section{'Silber's folly’ goes public}

Boston University (BU) will learn later this month what investors think of its controversial decision to invest nearly $\$ 100$ million over the past five years in a small biotechnology company.

The Hopkinton, Massachusetts, company, Seragen Inc., is preparing its first public offer of three million shares -25 per cent of the company. If successful, the offer will raise enough money to support the company for the next 30 months and derive a product from its technology, which uses genetically engineered fusion toxins to kill disease-carrying cells. It will also enable the university to end its monthly infusion of $\$ 1.2$ million into the company, drawn from the school's endowment.

If the stock market responds as well as BU is predicting, university president John Silber will have proved wrong the critics of his 1987 decision to invest the equivalent of one-fifth of the university's endowment in the company. With shares priced at between $\$ 17$ and $\$ 20$ each, Seragen would be worth $\$ 166$ million on paper - almost $\$ 70$ million more than BU has invested.

But Wall Street may not see it the same way. Peter Drake, an analyst with Vector Securities International, points out that eight of the 11 biotechnology companies that have gone public so far this year failed to get their asking price. As a group, they are now trading at an average of ten per cent under their initial value. Compared to last year's biotechnology gold rush, he says, "the class of 1992 are underproducers".

Whatever the outcome, BU says it is not baling out of Seragen. Even after the stock sale, the university will still own almost 70 per cent of the company. Nor, officials say, has the university lost confidence in the company's commercial promise, despite the potential damage from the outcome of patent infringement claims filed by two companies and the possibility that the attorney general of Massachusetts could decide that the university's investment is not prudent and force BU to sell its shares.

Christopher Anderson been translated into Chinese and was being widely used.

A few days after the Israelis returned home, Chinese tanks rolled into Tiannanmen Square to suppress the student uprising. Although China's use of military force against its own citizens invoked a strong reaction from the international scientific community, it proved to be a boon to the deepening Israeli-Chinese relationship. In fact, Israeli officials believe that China reacted with uncharacteristic speed to their political overtures in part to counteract their feelings of isolation brought on by sanctions imposed by much of the rest of the world.

As a result, what was expected to take years bore fruit in a matter of months. In November, Merhav and Zadok flew to New York to meet Li Lu Ye, the Chinese ambassador to the United Nations. They agreed that the Israeli academy would set up a liaison office in Beijing and that China would open a tourism office in Tel Aviv. The Israeli office - the first official Israeli presence in China - opened in April 1990. It was headed by Yossi Shalhevet, a 60-year-old agronomist and former director of the Volcani Research Institute.

"He's straightforward and he's warm," says Zadok about Shalhevet. "He's probably the best diplomat that Israel has."

Shalhevet says that the Chinese especially admire Israel's military prowess and its success in making the desert bloom. "They attribute our successes to the use of science and technology, which today is the highest priority in China," he says.

Once he arrived in Beijing, Shalhevet began to tour universities and scientific institutions throughout China. He paved the way for 100 Israeli scientists to visit China, and likewise for 50 Chinese scientists to tour Israel. He began a student exchange program and initiated research symposia.

Building upon his success, Merhav again met the Chinese ambassador to the UN in October 1990. He argued that the forthcoming peace talks on the Middle East required the posting of an experienced diplomat in its Chinese liaison office. The Chinese agreed, and last year an Israeli diplomat joined Shalhevet.

The multinational peace conference in Moscow last December further accelerated the process. Israel agreed to China's wish to participate in the talks only after China acceded to its request for full diplomatic relations.

Shalhevet remains in the Beijing office as scientific liaison. He says he is now busier than ever, bringing together business officials as well as arranging visits to Israel by Chinese scientists and students. Abraham Rabinovich 